\title{
Three Pragmatist Legacies in the Thought of Umberto Eco
}

Claudio Paolucci

\section{OpenEdition}

1 Journals

Electronic version

URL: http://journals.openedition.org/ejpap/1232

DOI: 10.4000/ejpap.1232

ISSN: 2036-4091

\section{Publisher}

Associazione Pragma

\section{Electronic reference}

Claudio Paolucci, «Three Pragmatist Legacies in the Thought of Umberto Eco », European Journal of Pragmatism and American Philosophy [Online], X-1 | 2018, Online since 20 July 2018, connection on 24 September 2020. URL : http://journals.openedition.org/ejpap/1232 ; DOI : https://doi.org/10.4000/ ejpap. 1232

This text was automatically generated on 24 September 2020.

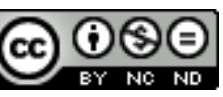

Author retains copyright and grants the European Journal of Pragmatism and American Philosophy right of first publication with the work simultaneously licensed under a Creative Commons AttributionNonCommercial-NoDerivatives 4.0 International License. 


\title{
Three Pragmatist Legacies in the Thought of Umberto Eco
}

\author{
Claudio Paolucci
}

\section{Eco and Pragmatism}

1 Pragmatism was one of the greatest influences on Umberto Eco's intellectual adventure. This influence can be seen not only in his philosophical work, but also in many of the ideas hidden behind his novels, which, as Eco himself had recently admitted by authorising the Library of Living Philosophers to extensively cover such a topic in the volume dedicated to him, are an important part of his philosophy. Or, perhaps, Eco's novels should be called a "non-philosophy" that, in his line of thinking, constitutes a component of philosophy itself and of his entirely unique way of practising it (see Paolucci 2017a). Certainly, Eco always admitted the more than evident influence of Peirce on his semiotics and his thought. And his idea that semiotics was a decisive part of philosophy, if not the "contemporary form of philosophy" itself (Eco 1984; 2017) was influenced by Peirce's thought. It is equally certain that different studies have concentrated on the relationship between Eco's thought and that of Peirce (Proni 2015; Pisanty \& Pellerey 2004; Paolucci 2017b and Auxier, in this volume), shedding light on the connections between them, from the more evident to least obvious and immediate. In addition, the numerous dialogues that Eco had always tried to put together with the greatest exponents of American philosophy inspired by pragmatism, from Quine to Putnam (see Eco 1984; 1997) on down to that with Richard Rorty, ${ }^{1}$ which even lead to an important book on "interpretation and overinterpretation" (Eco 2002), are just as evident.

2 However, Eco's relationship with pragmatism was not limited to the single relationship with an author (however decisive it may have been for his thought), to the returning to a series of topics and problems, or to the dialogue with a group of philosophers that had always had great esteem for pragmatism. Quite to the contrary, in my opinion, Eco's thought was radically pragmatist in its ways and intentions and, on a deeper 
level, even in its specific style of thinking. It is no coincidence that Eco owed many of his theoretical turning points to the pragmatists, and not just Peirce.

His meeting with Dewey, who Eco credits, in his philosophical autobiography, with his liberation from a certain way of thinking of Italian culture at the time, can stand in as an illustrative example. ${ }^{2}$ It is certainly worth reading this account in the words of Eco himself.

I was interested in the study of aesthetics and, naturally, all beginners had to read the idealist philosopher Benedetto Croce. Even at that time I was beginning to think that Croce had not understood much about art, and in that sense I was rebelling against contemporary Italian culture, which still lay within the idealist camp. This was the reason why, in order to elude the influence of German idealist philosophers, who were mandatory reading for all Italian philosophy students, I (like many others of my generation) went in for French and Anglo-American philosophy. In my university years reading Dewey's Art as Experience was a liberation for me. (Eco 2017: 6)

And it is from the ideas of Art as Experience that, through his meeting with Luigi Pareyson, Eco was able to manage the true revolution for aesthetics that The Open Work was first for Italian culture and subsequently for European culture (see Paolucci 2017a, chapter 4).

The discussion around semiotics is not much different. In order to criticise the Crocederived idea of art as intuition, Eco was inspired by Pareyson's idea of interpretation. For Pareyson, not only was art not an introspective intuition which exhausts itself in internal elaboration, whereas its technical-material externalization is completely accessory, as Croce used to think. But, according to Pareyson "artistic production is not the sudden outcome of a not otherwise defined intuition but is, rather, a process of trial and error, and the patient questioning of a preexisting material" (Eco 2017: 18).

It was then Peirce's semiotics - anti-Cartesian essays and the works on abductive reasoning in particular - that Eco placed his trust in to further develop, epistemologically and cognitively speaking, all the points which were so decisive for him. And he always held great gratitude for the father of American pragmatism. According to Peirce: i) interpretation is a form of trial/error that has the shape of an abductive gamble and of the fallibility of a hypothesis; ii) interpretation as inference is the exact opposite of intuition, which is instead a "cognition that has not been determined by previous cognitions"; iii) the same "idea present to the mind," whether this be a representative thought or internal introspection, is never an intuition at all, but rather a sign derived from hypothetical inference starting from some external state.

7 Eco turned these three points into the very cornerstones of his semiotics and never let go, even after the cognitive reflections of Kant and the Platypus, which would have been able to inspire a return to a certain pre-semiotic form of intuition (see Eco 2007; Paolucci 2015). The same idea of interpretation, which would then become the label for his way of practising semiotics (interpretative semiotics), comes from here, from these problems and from these reflections.

The process-based approach to creation implies a similarly trial- and process-based notion of the response to the completed work, namely, its interpretation. This concept is central to Pareyson's aesthetics precisely because he takes into account the interaction between a world of forms (be they natural or produced by human beings) and the presence of human interpretive activity. The notion of interpretation, in Pareyson's view, is very broad and implies the enjoyment of the 
work of art, its possible performance, as well as its critique, and the translation of a text. Pareyson never quoted Peirce but the former's concept of interpretation led to my being won over by Peirce's notion of the interpretant, which (as we shall see) permeated my later semiotic approach. (Eco 2017: 18-9; original emphasis)

However, the relationship with pragmatism and with the pragmatists wasn't necessary for Eco simply to incite revolutions and, thus, to accelerate thought towards something new and unexpected, but also to put the brakes on it, in order to reject intellectual models that, in the era Eco was writing in, were colonising the cultural world. Thanks to pragmatism, Eco used to refuse ideas which he certainly did not consider desirable, even if they were at the centre of the cultural world.

Among the many contenders, the most important example is that of "Deconstruction." Eco was among the first to speak of "open work" and of the interpreter as a sort of coauthor of the work itself. However, Eco was never willing to accept Derrida's positions on these topics, and the most heated debate on his positions - in which Eco tried to refute Derrida's theses - is seen in the interpretation of Peirce's famous passage about "symbols grow" (CP 2.302), which Derrida had analytically commented on in of Grammatology. Eco, who had dedicated the very essence of his semiotic theory of interpretation to the idea of "infinite semiosis," appealed directly to the pragmatist idea of habit as a logical-final interpreter able to stabilise and dampen the interpretation, with the aim of not to acquiesce to the Derridean idea that Peirce was a precursor to the "deconstruction of the transcendental signified, which at one time or another would place a reassuring end to the reference from sign to sign" (Derrida 1967: 54). In this regard, Eco carries over the Peircean definition of lithium, "what you are to do in order to gain a perceptive acquaintance with the object of the word" (CP 2.330) and insists on the transcendental role of the "community as an intersubjective guarantee of a non-intuitive, non-naively realistic, but rather conjectural notion of truth" (Eco 1990: 39).

There isn't enough room here to go analytically through all the places in which the encounters with pragmatism and American philosophy were decisive in Eco's work. ${ }^{3}$ For this, I'll take another route and try to identify three large legacies of pragmatism which were central in Eco's thought and which shaped and influenced his philosophy to its foundations. The three of Eco's overarching ideas that are marked in their very essence by pragmatic legacy are: i) the non-separation of semantics and pragmatics; ii) the centrality of abduction for cognition and semiotic thought; iii) synechism, or rather, the continuity between mind and world that Eco was unwilling to allow on a theoretical level, but which he explicitly puts on stage in narration.

\section{Semantics, Pragmatism and the Pragmatic Maxim}

11 At first glance, it seems paradoxical to ascribe pragmatism's legacy to the consideration of pragmatics as a part of semantics, seeing as the three-pronged division into syntax, semantics and pragmatics derives from Charles Morris' interpretation of certain ideas coming from Peirce. And yet, Eco never loved Morris to the degree he viscerally loved Peirce and his pragmatism, and a few of Peirce's ideas coming from the very foundation of pragmatism were the ground of Eco's idea that pragmatics was part of semantics.

12 Personally, I'm firmly convinced that the non-separation of semantics and pragmatics is one of the most crucial ideas of Eco's semiotic legacy, one which hasn't been 
sufficiently considered and valued within a semantic landscape that uses Morris' tripartition as a starting point, if not a true cornerstone. I am also convinced that Eco's idea is the direct result of Peirce's pragmatic maxim, which, in A Theory of Semiotics, Eco applies to the most modern problems of cognitive semantics.

Peirce's pragmatic maxim is in fact a theory of meaning: "Consider what effects, that might conceivably have practical bearings, we conceive the object of our conception to have. Then, our conception of these effects is the whole of our conception of the object. [...] There is no distinction of meaning so fine as to consist in anything but a possible difference of practice." (CP 5.402).

In Seventies-era semantics, there was a tendency to enthusiastically distinguish between the meaning of a sign from its usage in language. Meaning wasn't about usage, and usage was actually a question of pragmatics, not semantics. This division tended to create numerous further distinctions, which Eco used to consider entirely artificial, such as that between dictionary and encyclopaedia and that between "knowledge of language" and "knowledge of the world" (see Eco 1975; 1984). We will start with the latter distinction: according to the semantic theories that Eco was opposed to, a knowledge of the language (dictionary) would concern the fact that a bachelor is an "unmarried male adult," while a knowledge of the world (encyclopaedia) would concern the fact that the author of this essay is a bachelor. According to Katz (1972), who is the author of a semantic theory that embodies the polemic goal of A Theory of Semiotics, encyclopaedic knowledge cannot be part of the meaning of a word since, as there are always new discoveries about the world (and thus new uses of words which have become the subject matter of common knowledge), this knowledge and these uses should be included in the semantic representation of a lexical item. For Katz, it was something that should not and must not be done, but, according to Eco (1975: 143-4), this was the very work of semantics itself. For this very purpose, in A Theory of Semiotics, Eco (1975: 152-72) tries to propose a semiotic model founded on "coding contexts and circumstances." As we will now see, these codified contexts and circumstances represent those very "conceivable practical effects" that, according to Peirce, identify meaning.

15 Let me unpack this point a bit. Eco's Reformulated Semantics Model (1975) inserts all of a sign's accepted meanings, along with the contextual and circumstantial selections that make it possible for us to use it within concrete linguistic practices (usages), into the semantic representation of that sign. "Contextual selections" make it possible to activate the correct meanings in function of the other, co-existing meanings of the sign in question. Meanwhile, "circumstantial selections" make it possible to activate the correct meanings in function of the events and objects that co-exist in concrete linguistic practices. More generally, "the way to represent the meaning of a signvehicle $\mathrm{x}$ is 'if $\mathrm{x}$ then, according to the following circumstances and contexts, the following interpretants will be activated"' (Eco 2017: 23). As such, the conceivable interpretative activity of the speaker, with the possible ways he could use language, becomes part of the semantic representation of a sign-vehicle, exactly like encyclopaedic knowledge, in its regularity, becomes a ineliminable component of semantics. It is a completely Eco-like way of interpreting the Peircean idea that, in order to determine the meaning of something, the conceivable practical effects must be determined. 
Thus, according to Eco, the circumstantial and contextual selections have nothing to do with the empirical contexts and the empirical circumstances in which a word is used. For Eco, meaning is not related in any way to empirical uses, with "the practical effects of signs," but rather with the conceivable empirical uses, with the conceivable practical effects of signs, which Eco calls "the codes of contexts and circumstances." It is clear how Eco is thinking here through Peirce's pragmatism and not through its version by William James (Sini 1971; Maddalena, Calcaterra \& Marchetti 2015). Meaning, in fact, does not consist in the identifiable practical effects of using a word. To the contrary, meaning consists in the conceivable practical effects, in other words (in Eco's semantic terminology), in the coding of contexts and circumstances, and thus in the concepts of the possible uses of a sign that are culturally and conventionally considered more probable.

The theory does not have to list and to structure all the possible occurrences of a given item but only those which are culturally and conventionally recognized as the more statistically probable. (Eco 1975: 110)

Eco does not dissolve meaning in its practical effects, just as he does not dissolve semantics in the empirical uses of speakers. Rather, he thinks that pragmatics, understood as a conceivable whole of the regularities of usage, is a constitutive component of meaning. For this reason, proper semantic representation must consider pragmatics to be a constitutive part of semantics itself. It is on this topic that Eco's pragmatist inspiration is not only evident, but sows the seed of what in my opinion is one of the most important ideas of semiotic semantics.

\section{Abduction}

In Paolucci $(2010 ; 2012)$, I have tried to reconstruct the profound evolution that the concept of abduction underwent within Peirce's thought. Initially thought of as the inference of the minor premise of a "Barbara" syllogism starting from the major premise and the conclusion, abduction became, according to the mature Peirce, a "strange salad" able to hold together i) a "token-type" logical movement, ii) an analogical "token-token" movement, and iii) the art of fantasizing able to connect heterogeneous universes of experience that Peirce would call musement. In this latter form (that of the "strange salad"), abduction became for Peirce the true driving force behind the process of cognition, representing the very fulcrum of semiosis.

It is therefore no coincidence that Eco dedicated numerous years and many studies to capturing the complexity internal to Peirce's concept of abduction, trying to classify its potential variants and to use them in every phase of his intellectual adventure, from philosophy to semiotics to novels. Let us take a look at how The Name of the Rose is an example based on this work on the idea of abduction. ${ }^{4}$

If I were to vote for a work of reference on these topics, I would not hesitate to choose "Corna, zoccoli, scarpe," an article originally published in the anthology The Sign of Three (then republished in The Limits of Interpretation), that, in my opinion, is also one of the most extraordinary essays by Eco the philosopher and semiotician. According to Eco, the idea of abduction has to do with that form of reasoning and interpretive process in which, standing before an unknown, surprising event that requires explanation, one (fallibly) gambles that this event could be the case of a rule (see CP 2.624). If the abduction is verified, thus discovering that the unknown event is 
effectively the case of that rule, that event thereby stops being surprising. For Eco, abduction is therefore an example of reasoning through which the unknown is brought back to the known, and "rules are produced to be able to interpret" (Eco 1997, chapter 2). However, and this is the real interesting part, according to Eco, abduction is a sort of umbrella term, as there are different types that show up for different types of risks and benefits.

In "Corna, zoccoli, scarpe," Eco provides one important classification, founded on a four-way partition. He calls the first type of abduction "hyper-codified." In this form, the rule is given and it is even codified and attested to, for which the abductive reasoning is effectively resolved in a token-type relationship, in which the unknown event is interpreted as the token of a general type that represents the law.

The second type of abduction is "hypo-codified." Here the relationship between case and rule is not codified and there are different possible rules, often equiprobable, which are made available to us by the semiotic encyclopaedia as a format of the "current knowledge of the world." The example which Eco gives for this type of abduction is Kepler's discovery of the elliptic nature of the orbit of Mars.

When Kepler discovered the ellipticity of the orbit of Mars, he met a surprising fact (the initial positions of the planet), then he had to choose between various geometrical curves, whose number was not infinite, however. Some previous assumptions about the regularity of the universe suggested to him that he had to look only for closed not transcendental curves (planets do not make random jumps and do not proceed by spirals or sine waves). (Eco 1983: 207)

The third type is "creative" abduction, in which it is the rule itself that must be created ex novo. According to Eco, this type of abduction is found in all revolutionary discoveries, whether they are scientific, historic or literary. This type of abduction is interesting because the type is not given, but it must be in turn posed or constructed, making abduction a fallible way to construct rules in order to be able to interpret and make sense of unknown, surprising results.

However, the most extraordinary type of abduction, the one in which Eco strikes gold, is the fourth and final form, which Eco calls "meta-abduction."

It consists in deciding as to whether the possible universe outlined by our first-level abductions is the same as the universe of our experience. In over- and under-coded abductions, this meta-level of inference is not compulsory, since we get the law from a storage of already checked actual world experience. In other words, we are entitled by common world knowledge to think that, provided the law is the suitable one, it already holds in the world of our experience. In creative abductions we do not have this kind of certainty. We are making a complete "fair guess" not only about the nature of the result (its cause) but also about the nature of the encyclopedia (so that, if the new law results in being verified, our discovery leads to a change of paradigm). As we shall see, meta-abduction is not only crucial in "revolutionary" scientific discoveries but also (and normally) in criminal detection. (Eco 1983a: 207)

Meta-abduction is abduction that has another abduction as its object and which presumes parallelism between worlds: it is first necessary to gamble on a possible explanation that creates a coherent story, which, however, we don't know if it corresponds effectively to the facts at hand (abduction object). It is then necessary to gamble that this abduction, object of the first wager, outlines a possible world that one gambles will be the same world as reality (meta-abduction). For this, Eco (1983) talks about "a sick Spinozist universe" in which ordo et connexio idearum (the world outlined 
by our first abduction) idem est ac ordo et connexio rerum (the real world). Metaabduction is the bet that the world we have hypothesized in our conjectures is one and the same as the real world. This parallelism between mind and world, which, as we will soon see, constitutes the very essence of Peircean synechism, is the mechanism that presides over the abductions of William of Baskerville and Jorge de Burgos in the extraordinary finale of The Name of the Rose. This further demonstrates that the relationship with pragmatism influenced Eco's thought on every level, including narrative. Indeed, the prime example of meta-abduction for Eco can be found in detective stories. It is no coincidence, then, that when Eco writes his, he has Borges' Death and the Compass in mind, which not by chance inspired the evil blind librarian who is the protagonist of the novel's finale.

To be sure that the detective's mind has reconstructed the sequence of events and laws as they should have been, you have to harbor a profound persuasion that "ordo et connexio rerum idem est ac ordo et connexio idearum." The movements of our mind that investigates follow the same laws of reality. If we think "well," we are obliged to think according to the same rules that connect things among themselves. If a detective identifies with the mind of the murderer he can only get to the point to which the murderer gets. In this Spinozan universe the detective is not just the one who understands what the murderer has done (because he could not fail to do that, if there is a logic to the mind and things). In this Spinozan universe the detective will also know what the murderer will do tomorrow. And he will go to wait for him at the place of his next crime. But if the detective can reason this way, so can the murderer: who can do things in such a way that the detective goes to wait for him in the place of his next crime, except that the victim of the murderer's next crime will be the detective himself. And this is what happens in "Death and the Compass." (Eco 1983b: 170)

This is also the case in The Name of the Rose. Having understood that William of Baskerville had gambled that the murderer was following the "scheme of the Apocalypse" for his crimes, Jorge de Burgos begins following the scheme himself, even if all the previous murders were actually the result of chance and not an elaborate or preconceived plan.

Yet, according to Eco, there is one major difference regarding the force of metaabduction when it operates within the real world or when it operates within the fictional world, as is the case in his novel. It is certainly possible to create metaabductions in the real world as well, and Eco cites not only certain scientific discoveries as paradigmatic examples, but also historic discourse and conjectures from the history of medicine. However, unlike that which happens in the real world, a detective like Sherlock Holmes never makes mistakes and he never hesitates to meta-gamble that the world which he has charted out is the same as the "real" world, since he has the privilege of living in a world constructed by his inventor, Sir Arthur Conan Doyle, who constantly verifies all hypotheses. In the real world, on the other hand, there is nothing which corresponds to the author of a novel, unless one wants to assume the point of view of God, something which Eco is not willing to do and which had already consumed his distancing from the Christian thought of his teacher, Luigi Pareyson. Pareyson believed in the existence of a "creator" who authored the shapes of the world, analogous to the author of a novel, able to ensure the abductive reasoning of his "characters." Precisely because he is unwilling to make this move, Eco feels the need to insist - consistently and on more than one occasion - that meta-abductions are dangerous and should always be verified empirically, just as wary researchers consistently try to do in criminal, medical or philosophical investigations. 


\section{Synechism} of pragmatism. Peirce was convinced that all human beings have a sort of "lume naturale," a natural instinct to guess correctly, as our brain evolved in accordance with things themselves. This leads to the most decisive metaphysical and epistemological idea from the mature Peirce, who considered it the very key of his own philosophical system (Maddalena 2009): the existence of continuity between mind and world. According to Peirce, the mind is the part of the world through which the world represents itself. It is not by chance that, like the mind, the world also tends to taken on habits, and thus has a "tendency to behave in a similar way under similar circumstances in the future" (CP 5.487). In this regard, Eco, analysing Peirce's synechism and its relationship with pragmatism in The Role of the Reader, noted how the logical-final interpretant for Peirce always expresses "the same law governing the Dynamic Object." This is why we have a natural instinct to guess correctly, as our mind follows the same laws according to which the world is itself organised.

However, even if he perfectly knew these ideas, Eco never wanted to follow in Peirce's footsteps on this matter. He always professed disagreement both with the idea of a lume naturale and with the ability to guess correctly guaranteed by a mind that is naturally in harmony with the structure of things (Eco 1983b: 334-9). This is why, for Eco, metaabductions were always "a worrying question" (Eco 1983a: 258). There is nothing in the structure of the world or in that of evolution that guarantees our conjectures. To the contrary, in Eco's opinion, man is structurally devoted to falsity and error, constantly running the risk of remaining a victim of his own semiotic creations, which he uses to try to decipher the disorder of the world, but which often do nothing besides show him his own signs and references. This is the "force of falsity" that Eco always puts on stage in his novels. Starting from false ideas and incorrect conjectures, man is certainly able to discover many truths, but these discoveries are often the result of chance and error, just like those of William of Baskerville, who manages to truly discover the murderer of the abbey and his mysteries by following the false scheme of the Apocalypse.

Thus, as I tried to show in Paolucci 2017, for Eco, synechism is not a constitutive principle (as it was for Peirce), but rather a regulative one. We act "as if" our conjectures correspond to the structure of the real world. We would be unable to gain experience without this meta-abductive gamble. However, there is nothing in the structure of the world that guarantees the Spinozan parallelism that serves to secure our abductions, just as Sir Arthur Conan Doyle did with those of Holmes. In the real world, unlike that of fiction, synechism is something that we tentatively try to impose on the world's chaos in order to produce an order, without, however, any guarantee that this order actually exists.

I have never doubted the truth of signs, Adso; they are the only thins man has with which to orient himself in the world. What I did not understand was the relation among signs. I arrived at Jorge through an apocalyptic pattern that seemed to underlie all the crimes, and yet it was accidental. I arrived at Jorge seeking one criminal for all the crimes and we discovered that each crime was committed by a different person, or by no one. I arrived at Jorge pursuing the plan of a perverse and rational mind, and there was no plan, or, rather, Jorge himself was overcome by his own initial design and there began a sequence of causes, and concauses, and of 
causes contradicting one another, which proceeded on their own, creating relations that did not stem from any plan. Where is all my wisdom, then? I behaved, stubbornly, pursuing a semblance of order, when I should have known well that there is no order in the universe [...] The order that our mind imagines is like a net, or like a ladder, built to attain something. But afterward you must throw the ladder away, because you discover that, even if it was useful, it was meaningless. (Eco 1980:

426)

This is why Eco finds it necessary to "laugh at the truth": truth, being a form of correspondence between intellect and things on the one side and between the mind and the world on the other side, is a form of order that we try to impose on the world to gain experience. However, many other orders are possible. This is why it is always a good idea not to take just one too seriously. One order may seem to be particularly stable or reasonable to us, so we may think that this is the truth. However, according to Eco, the truth is often nothing other than an attested version of the world which is the effect of research that must never be interrupted, but which should always be entrusted to the uncertain logic of interpretation and conjecture.

\section{This Issue}

Insofar as in this piece I have tried to shine some light on three aspects that, in my opinion, are anything but banal in terms of the relationship between Eco and pragmatism, it is clear that the authors participating in this issue of the European Journal of Pragmatism and American Philosophy will investigate the relationship between Eco's thought and that of American pragmatist traditions from their own points of view.

For instance, Randall Auxier works on the relationship between Eco and Peirce, with special attention to semiotics, introducing an original interpretation of many ideas about this topic. Francesco Bellucci also works on a classic topic, that lies at the heart of the relationship between Eco and pragmatism: the idea of abduction and the justification of abductive reasoning. Bellucci argues that both Peirce and Eco solved this problem through the idea that the justification of abduction is itself abductive.

Also Valentina Pisanty deals with one major theoretical problem, the "keeping together" of Structuralism and Pragmatism inside Umberto Eco's work. In order to account for that, Pisanty introduces the idea of bisociation, that, though never an item of Eco's own philosophical toolbox, plays an important role in the creation of a possible/impossible graft between Structuralism and Pragmatism.

Conversely, Martin Švantner deals with the late Eco's ideas on semiotics, connected to cognitive sciences and to the problem of qualia. In his view, Eco started to focus specifically on the problem of qualia mostly in his later period when he turned from the idea of almost universal theory of semiotics (as in A Theory of Semiotics) to cognitive realism (in Kant and the Platypus) with the help of more precise reinterpretation of Peirce's concepts.

34 Also Rossella Fabbrichesi's paper deals with a late idea of Umberto Eco's production, negative realism. According to Fabbrichesi, Eco's appeal to Peirce's distinction between Immediate and Dynamical Object is contaminated by a common-sense interpretation of what 'real' is, which is note what Peirce had in mind with his distinctions. 


\section{BIBLIOGRAPHY}

CAlCATERra Rosa Maria, (2017), Filosofia della contingenza. Le sfide di Richard Rorty, Genoa, Marietti. ECO Umberto, (1975), A Theory of Semiotics, Bloomington, Indiana University Press.

ECo Umberto, (1980), Il nome della rosa, Milan, Bompiani (English translation, The Name of the Rose, New York, Harcourt)

ECO Umberto, (1983a), “Corna, Zoccoli, Scarpe," in Umberto Eco \& Thomas A. Sebeok (eds), Il segno dei tre, Milan, Bompiani.

ECO Umberto, (1983b), Sugli specchi e altri saggi, Milan, Bompiani.

ECO Umberto, (1984), Semiotica e filosofia del linguaggio, Turin, Einaudi.

ECO Umberto, (1990), The Limits of Interpretation, Bloomington, Indiana University Press.

ECo Umberto, (1997), Kant e l'ornitorinco, Milan, Bompiani.

ECO Umberto, (2002), Interpretazione e sovrainterpretazione, Milan, Bompiani.

ECO Umberto, (2007), “The Threshold and the Infinity," in Id., From the Tree to the Labyrinth: Historical Studies on the Sign and Interpretation, Cambridge, Harvard University Press.

ECO Umberto, (2017), “Intellectual Autobiography," in Sara G. Beardsworth \& Randall E. Auxier (eds), The Philosophy of Umberto Eco, Chicago, Open Court, 3-65.

KATZ Jerrold J., (1972), Semantic Theory, New York, Harper \& Row.

MADDALENA Giovanni, (2009), Metafisica per assurdo. Peirce e l'epistemologia contemporanea, Cosenza, Rubbettino.

MADDALENA Giovanni, CALCATERRA Rosa Maria \& Giancarlo MARCHETTI (eds), (2015), Il pragmatismo. Dalle origini agli sviluppi contemporanei, Rome, Carocci.

PAOLuCCI Claudio, (2010), Strutturalismo e interpretazione, Milan, Bompiani.

PAOLUCCI Claudio, (2012), “Abduzione e interpretazione. Abbiamo davvero ascoltato Peirce?,” in Ivan Pozzoni (ed.), Le varietà dei pragmatismi, Villasanta, Limina Mentis, 57-78.

PAOLUcci Claudio, (2017a), Umberto Eco. Tra Ordine e Avventura, Milan, Feltrinelli. 
PAolucci Claudio, (2017b), "Eco, Peirce, and the Anxiety of Influence: The Most Kantian of Thinkers," in Sara G. Beardsworth \& Randall E. Auxier (eds), The Philosophy of Umberto Eco, Chicago, Open Court, 251-278.

PEIRCE Charles Sanders, (CP), Collected Papers, Cambridge, Harvard University Press.

PISANTY Valentina \& Roberto PELLEREY, (2004), Semiotica e interpretazione, Milan, Bompiani.

PRONI Giampaolo, (2015), “Umberto Eco and Charles Peirce: A Slow and Respectful Convergence," Semiotica, 206 (1/4), 13-35.

SINI Carlo, (1971), Il pragmatismo americano, Rome, Bari, Laterza.

\section{NOTES}

1. See Calcaterra 2017.

2. See Robert Innis' paper in this issue for a detailed account on that.

3. I partially have done so in my book, Umberto Eco. Tra Ordine e Avventura (Paolucci 2017a).

4. Comparable examples could be made for all of Eco's novels. On this point, see Paolucci (2017a, chapters 9 and 10).

\section{AUTHOR}

\section{CLAUDIO PAOLUCCI}

University of Bologna

c.paolucci[at]unibo.it 